\title{
Pengaruh Kepemimpinan dan Disiplin Kerja Terhadap Kinerja Birokrasi Pelayanan Publik pada Kantor Kecamatan Buntu Batu Kabupaten Enrekang
}

\author{
Saidiman', Sandi Lubis², Rais Rahmat Razak³, Ahmad \\ Mustanir ${ }^{4}$ \\ 1,2,3,4 Magister Ilmu Administrasi Publik, Program Pascasrjana, Universitas \\ Muhammadiyah Sidenreng Rappang, Sulawesi Selatan, Indonesia \\ Saidiman12@gmail.com! sandi.lubis@gmail.com², \\ mraisrahmat@yahoo.com ${ }^{4}, \underline{\text { ahmadmustanir74@gmail.com }}{ }^{5}$
}

\begin{abstract}
Abstrak_Banyak fenomena yang terjadi dilapangan terutama lingkup kantor Kecamatan Buntu Batu Batu belum menunjukkan keadaan yang lebih menggembirakan. Hal ini dilihat dari hasil observasi kinerja pegawai kecamatan masih belum optimal dalam melaksanakan kewenagan, tugas, fungsi serta kewajibannya dibidang pemerintahan. tujuan penelitian ini untuk mengatahui disiplin kerja dan kepemimpinan camat terhadap kinerja birokrasi pelayanan publik di Kantor camat Buntu Batu. Metode yang digukan pada penelitian ini kuantitatif deskriptif. Teknik pengumpulan sampel dilakukan dengan model sensus, yaitu mengambil semua populasi sebanyak 33 orang responden yang ada pada kantor kecamatan dan 8 desa se Kecamatan Buntu Batu yang terdiri PNS dan tenaga honorer. Analisis statistik yang saya gunakan dalam menguji hipotesis dalam penelitian ini adalah analisis table frekuensi, produkmoment dan regresi linear berganda. Proses perhitungan dilakukan dengan analisis SPSS versi 23. Hasil analisis menunjukkan bahwa:I) kepemimpinan camat berpengaruh nyata terhadap kinerja birokrasi pada pelayanan dikantor Camat Buntu Batu sangat ditentukan oleh Gaya kepemimpinan; 2) ada pengaruh yang nyata antara disiplin kerja terhadap kinerja birokrasi pelayanan publik di kantor Camat Buntu Batu yang ditentukan oleh dimensi ketaatan dan kepatuhan; 3) kepemimpinan dan disiplin kerja secara simultan berpengaruh nyata terhadap kinerja birokrasi pelayanan publik dikantor kecamatan buntu batu. Hal ini menunjukkan bahwa jika Camat menerapkan gaya kepemimpinan Demokratik dan kedisiplin pegawai meningkat secara bersamasama akan meningkatkan kinerja birokrasi pelayanan publik di kantor Camat Buntu Batu.
\end{abstract}

Kata Kunci - Kepemimpinan, Disiplin Kerja, Pelayanan Publik.

\section{PENDAHUluaN}

Disiplin kerja dilihat dari berbagai aspek yaitu kehadiran, mematuhi peraturan dan tatatertib dari instansi. Pegawai yang memiliki disiplin kerja yang tinggi akan melaksanakan tugas atau pekerjaanya dengan tertib, sehingga secara langsung akan memberikan dampak baik pula 
bagi instansi. Dengan adanya kepemimpinan dan disiplin kerja yang baik maka diharapkan para pegawai dapat menyelesaikan tugas atau pekerjaan dengan hasil yang lebih baik serta semangat dan dorongan bertambah sehingga akan berpengaruh pada peningkatan kinerja pegawai.

Peningkatan

kinerja

pegawai secara keseluruhan pada suatu instansi akan meningkat pula kelancaran dalam proses kerja. Dan dengan kelancaran proses kerja akan mempermudah tercapainya tujuan dari organisasi atau instansi yang bersangkutan. Kinerja pegawai merupakan hal penting yang harus diperhatikan oleh setiap instansi dimanapun tidak terkecuali bagi Kantor Kecamatan Buntu Batu Kabupaten Enrekang.

Salah satu upaya instansi dalam mempertahankan kinerja birokrasi pelayanan publik adalah dengan cara memperhatikan kepemimpinan dan disiplin kerja pegawai yang merupakan salah satu faktor yang sangat penting untuk mendapatkan hasil kerja yang terjadi dilapangan, terutama lingkup kantor Kecamatan Buntu Batu Batu belum menunjukkan keadaan yang menyenangkan.

$\mathrm{Hal}$ ini dilihat dari hasil observasi kinerja pegawai kecamatan masih belum optimal dalam melaksanakan kewenagan, tupoksi serta kewajibannya dibidang pemerintahan. Presentase kinerja pegawai
Kantor Kecamatan Buntu Batu tingkat pencapaiannya belum optimal. Hal ini terlihat hampir semua jenis kegiatan tingkat capaiannya belum optimal sebagai pelayanan publik.

Dari kehadiran pegawai diperoleh data pegawai yang mengikuti apel pagi dalam tiap minggunya hanya $50 \%$ dari jumlah pegawai, begitupun sebaliknya yang mengikuti apel sore, dari data diatas dapat disimpulkan bahwa kedisiplinan pegawai pada kantor Camat Buntu Batu masih kurang. Data ini dipertegas dengan hasil wawancara kepada pegawai yang notabene selaku kepala seksi merangkap PPTK (Pelaksana Teknis Kegiatan) yang diperoleh fakta bahwa Pimpinan dalam hal ini Camat dalam menjalankan kepemimpinannya menggunakan gaya kepemimpinan Paternalistik, hal tersebut berdampak pada kedisiplinan pegawai yang menurun sehingga menimbulkan beberapa masalah di Kantor Kecamatan Buntu Batu Kabupaten Enrekang antara lain : (I) aparatur birokrasi masih terkadang tidak menyelesaikan pekerjaan sesuai dengan target yang ditentukan, (2) aparatur birokrasi cenderung tidak mampu menyelesaikan pekerjaan sesuai dengan waktu yang telah ditentukan, (3) kurang terjalinnya koordinasi diantara aparatur birokrsi dalam menyelesaikan pekerjaan; dan (4) aparatur masih cenderung mementingkan ego 
masing-masing dalam menyelesaikan pekerjaan.

Kecamatan sebagai intitusi atau organisasi yang didalamnya terhimpun unsur-unsur yang masing-masing baik secara kelompok maupun individu dalam melakukan hubungan kerjasama untuki mencapai tujuan, unsuunsur yang dimaksud tidak lain adalah sumber daya manusia yang terdiri dari camat, pegawai (staf), aparat Desa dan masyarakat.

\section{Dengan}

Tidak mengenyampingkan peran dari unsur-unsur lain dari organisasi kecamatan, camat dan pegawai kecamatan merupakan orang dalam yang sangat berperan terhadap pelayanan dikecamatan.

Pencapaian

tujuan

organisasi sebagaimana yang diinginkan Bupati Enrekang yang melimpahkan kewenangan tersebut, sangat tergantung pada kemampuan camat dalam mewujudkan kewenangankewenangan yang dimilikinya dalam suasana kerja yang kondusif dan disiplin kerja yang tinggi, yang pada akhinya diharapkan akan menghasilkan suatu kinerja birokrasi pelayanan publik yang ditetapkan. Sehubungan dengan pelaksanaan pelimpahan kewenangan tersebut diatas, maka sudah terlihat begitu besar peranan camat dalam melaksanakan kegiatan pemerintahan, kemasyarakatan dan pembangunan.

Dari data yang diperoleh peneliti berkesimpulan ada masalahan Camat dalam memimpin pegawai. Pada proses ini pemimpin memiliki peran yang sangat erat menentukan dalam pelaksanaan instansi. Peran Pemimpin tidak hanya mengarahkan dan membimbing bawahan, namun yang perlu diperhatikan bahwa pemimpin itu mampu memberikan visa dan misi dan arah yang jelas kemana organisasi itu dibawa.

Kinerja karyawan/pegawai yang baik akan mempengaruhi berhasil atau tidaknya suatu tujuan instansi serta dapat pula membantu pimpinan dalam membuat keputusan. Salah satu faktor yang perlu diperhatikan untuk meningkatkan kinerja pegawai adalah kepemimpinan yaitu bagaimana agar kepemimpinan yang diterapkan oleh pemimpin dapat menunjang kinerja pegawainya agar lebih baik.

Faktor lain yang mempengaruhi kinerja pegawai selain kepemimpinan, yaitu faktor disiplin kerja. Sumber daya manusia dalam suatu instansi merupakan faktor penting agar instansi tersebut tetap unggul dan eksis selain dari faktor keuangan dan produksi. Semua instansi tentu memiliki standar perilaku yang harus dilakukan dalam hubungannya dengan pekerjaan, baik yang tertulis maupun yang tidak tertulis, dan menginginkan agar pegawai mematuhi sebagai 
upaya meningkatkan

produktivitas, namun pada kenyataannya yang terjadi pegawai tak lepas dari kelemahan, diantaranya masalsah kedisiplinan. Peningkatan Disiplin menjadi bagian yang penting dalam manajemen sumber daya manusia, sbeagai faktor penting dalam peningkatan produktivitas. Permasalahan yang kemudian muncul adalah Bagaimana Usaha yang dilakukan untuk meningkatkan disiplin Kerja pegawai. Pemimpin idealnya ada untuk memberikan perhatian serius dalam membina, mengarahkan dan menggerakan para pegawai di lingkungannya agar dapat mewujudkan stabilitas instansi peningkatan produktivitas yang beorientasi pada tujuan organisasi.

Disiplin kerja juga sangat penting dalam menentukan tujuan instansi tersebut dapat tercapai atau tidak. Disiplin pada dasarnya mencerminkan besarnya tanggung jawab seorang terhadap tugas yang diberikan kepadanya. Pegawai yang memiliki disiplin kerja yang baik tentu akan menghasilkan kinerja yang baik pula. Disiplin kerja akan menigkatkan kinerja pergawai. Kedisiplinan yang tidak dapat ditegakkan maka kemungkinan besar tujuan instansi yang telah direncanakan tidak akan tercapai secara efektif dan efisien. Melihat dari masalah yang ada maka peneiti menguraikan beberapa rumusan masalah seperti seberapa besar pengaruh kepemimpinan,

Pengaruh Disiplin Kerja terhadap kinerja pelayanan public dan seberapa besar pengaruh kepemimpinan dan disiplin kerja serta faktor-faktor apa apa saja yang mempengaruhi kepemimpinan dan disiplin kerja pelayanan public di kabupaten enrekang adapun tujuan dari penelitian ini untuk menjawab semua rumusan masalah yang ada.

Diharapakan penelitian ini dapat menjadi bahan masukan bagi pemerintah dalam hal ini para pejabat atau para birokrat Kabupaten Enrekang dalam rangka promosi jabatan di struktur pemerintahan Kabupaten Enrekang. Kepemimpinan pada dasarnya berasal dari kata "pimpin" yang berarti bombing atau tuntun. Dari kata benda "pemimpin" melahirkan kata kerja "memimpin" yang artinya memberi jalan atau menuntun.

Kata benda pemimpin adalah orang yang memiliki fungis memimpin atau menuntun (Kamus besar Bahasa Indonesia). Sedangkan Terry dalam kamaruddin, $\quad 2016$ mengemukakan bahwa, kepemimpinan adalah hubungan antara orang , dimana pemimpin mempengaruhi orang laing kearah kemauan Bersama dalam hubungannya dengan tugas untuk memeroleh sesuatu yang di 
inginkan oleh pimpinan.

Selanjutnya G.L Freeman dan E.K. Taylor kemepimpinan merupakan kelebihan untuk menciptakan kegiatan kelompok untuk mencapai tujuan organisasi dengan efektivitas maksimal dan kerjasama dari setiap individu. Kepemimpinan tidak hanya berarti pimpinan terhadap manusianya, tetapi juga pemimpin terhadap sebuah organisasi. Seorang pemimpin tidak hanya dapat mempengaruhi anak buah, tetapi juga ia menjadi sumber inspirasi dan motivasi bagi bawahannya.

Oleh karena itu, penafsiran dan definisi kemepimpinan semakin beragam dalam perkembanganya. Katz dan Kahn Dalam (Mustafa,20 I4), mengatakan bahwa kepemimpinan adalah tambahan pengaruh yang mengatasi keputusan mekanis pada pengaruh rutin organisasi, dengan kata lain kepemimpinan terjadi jika seseorang individu dapat mempengaruhi orang lain untuk mengerjakan sesuatu atas kemauanya sendiri dan bukan mengerjakan karena kewajiban atau takut dan konsekuensi dari ketidakpatuhan.

Unsur sukarela inilah yang membedakan kepemimpinan dengan proses pengaruh lainnya seperti kekuasaan dan wewenang. Rivai (20I5:2), dalam bukunya "Kepempinan dan perilaku organisasi” menyatakan bahwa definisi kepempinan secara luas, adalah meliputi proses mempengaruhi dalam menentukan tujuan instansi, motivasi bawahan untuk mencapai tujuan,mempengaruhi interprestasi mengenai peristiwaperistiwa para pengikutnya, pengorganisasian dan aktivitasaktivitas untuk mencapai sasaran, memlihara hubungan kerjasama dan kerja kelompok, perolehan dukungan dan kerjasama dari orang diluar kelompok atau organisasi.

Wursanto dalam bukunya dasar-dasar ilmu Organisasi $(2002 ; 197)$ menjelaskan teori kepemimpinan adalah bagaiamna seorang menjadi pemimpin, atau bagaimana memunculkan seorang pemimpin.

I. Teori kelebihan ini menganggap bahwa seorang akan menjadi pemimpin apabila ia memiliki kelebihan dari pada pengikutnya. Pada dasarnya kelebihan yang harus dimiliki oleh seorang pemimpin mencakup 3 hal penting yaitu, kelebihan ratio, kelebihan rohaniah, kelebihan badaniah.

2. Teori sifat. Teori ini mengemukakan bahwa seorang dapat menjadi pemimpin yang ideal apabila memiliki sifat-sifat yang positif sehingga para pengikutnya menjadi pengikut yang patuh, sifat kepemimpinan yang umum 
misalnya, adil, suka melindungi, penuh percaya diri,inisiatif,berdayaTarik,en ergik,komunikatif,persuasive , dan kreatif.

3. Teori Keturunan. Menurut teori ini, seseorang dapat menjadi pemimpin karena beberapa faktor yakni, karena keturunan atau warisan, karena orang tuanya seorang pimpinan dan iapun menggantikan orang tuanya.

4. Teori Kharismatik.Teori ini menganggap bahwa seseorang dapat menjadi pemimpin apabila memiliki charisma yang baik.Pemimpin ini biasanya memiliki daya Tarik Pemimpin ini biasanya memiliki daya Tarik, kewibawaan dan pengaruh yang sangat besar.

5. Teori Bakat. Teori ini sering juga disebut teori ekologis, ang berpendapat bahwa pemimpin lahir karena adanya bakat. la menjadi pemimpin karena memang mempunyai bakat untuk menjadi pemimpin. Bakat kepemimpinan harus dikembangkan, misalnya memberi kesempatan orang tersebut menduduki sebuha jabatan.

6. Teori Sosial. Teori ini menganggap bahwa setiap orang dapat menjadi pemimpin. mempunyai potensi untuk menjadi pemimpin asal diberikan kesempatan. setiap orang dapat dididik menjadi pemimpin karena masalah kepemimpinan dapat dipejari, baik secara formal maupun non formal. Fungsi kepemimpinan berhubungan dengan situasi social dalam kehidupan kelompok/organisasi dimana fungsi kepemimpinan harus diwujudkan dalam interkasi antar individu.

Menurut Rivai (2005:53) secara opreasional fungsi pokok kepemimpinan dapat dibedakan sebagai berikut :

I. Fungsi Instruktif, Fungsi ini bersifat komunikasi satu arah. Pemimpin sebagai komunikator merupakan pihak yang menentukan apa, bagaimana, bilamana, dan dimana perintah itu dikerjakan agar keputusan dapat dilaksanakan dengan efektif. Kepemimpinan yang efektif memerlukan kemampuan untuk menggerakkan dan memotivasi orang lain agar melaksankan perintah.

2. Fungsi Konsultatif, Fungsi ini bersifat komunikasi dua arah. Pada tahap pertama dalam menetapkan keputusan, pemimpin kerapkali memerlukan bahan pertimbangan yang mengharuskan berkonsultasi 
dengan orang-orang yang dipimpinnya yang dinilai mempunyai berbagai bahan informasi yang diperlukan dalam menetapkan keputusan. Tahap berikutnya konsultasi dari pimpinan pada orang-orang yang dipimpin dapat dilakukan setelah keputusan ditetapkan dan sedang dalam pelaksanaan. Konsultasi itu dimaksudkan untuk memperoleh masukan berupa umpan balik (feedback) untuk memperbaiki dan menyempurnakan keputusan yang telah ditetapkan dan dilaksanakan. Dengan menjalankan fungsi konsultatif dapat diharapkan keputusan pimpinan, akan lebih mudah

menginstruksikannya

sehingga kepemimpinan berlansung secara efektif.

3. Fungsi Partisipasi, Dalam menjalankan fungsi ini pemimpin berusaha mengaktifkan orang yang dipimpimpinnya, baik dalam keikutsertaan mengambil keputusan maupun dalam melaksanakannya. Partisipasi bukan berarti berbuat semaunya, namun dilakukan secara terkendali dan terarah dalam bentuk kersama dengan tidak mencampuri tugas pokok yang lain. Keikutsertaan pimpinan harus tetap dalam fungsi sebagai pemimpin dan bukan pelaksana. Fungsi Delegasi. Fungsi ini dilaksanakan dengan memberikan pelimpahan wewenang membuat dan menetapkan keputusan, baik melalui persetujuan maupun tidak dari pimpinan.

4. Fungsi delegasi pada dasarnya adalah kepercayaan.

5. Fungsi penegendalian. Fungsi pengendalian bermaksud bahwa kepemimpinan yang sukses mampu mengatur aktivitas anggotanya secara terarah dan dalam kordinasi yang efektif, sehingga tercapianya tujuan berdama secara maksimal. Fungsi pengendalian ini dapat diwujudkan melalui kegiatan bimbingan,pengarahan, kordinasi, dan pengawasan.

Gaya kepemimpinan merupakan perilaku yang digunakan seseorang pada saat orang tersebut mencoba mempengaruhi orang lain seperti yang dia lihat. Kebanyakan orang menganggap gaya kepemimpinan merupakan tipe kepemimpinan orang yang bersangkutan.

Setiyawan dan Waridin (2006:I0I), ada 5 faktor dalam menilai disiplin kerja terhadap pemberian layanan pada masyarakat yaitu: (I) kualitas disiplin kerja, meliputi datangdan pulang tepat waktu, pemanfaatan waktu dalam melaksanakan tugas dan mengembang potensi diri 
berdasarkan motivasi yang positif; (2) kuantitas pekerjaan meliputi volume keluaran dan konstibusi; (3) Kompensasi yang diperlukan meliputi : saran, arahan atau perbaikan. (4) lokasi tempat kerja atau tempat tinggal; konservasi meliputi penghormatan terhadap aturan dengan keberanian untuk selalu melakukan pencegahan terjadinya tindakan yang bertentangan dengan aturan.

Terdapat

empat perspektif yang menyangkut disiplin kerja menurut Rivai (200 14:444): (I) disiplin retributf (retributive Discipline) yaitu berusaha menghukum orang yang berbuat salah; (2) Disiplin korektif (corrective Discipline) yaitu berusaha membantu pegawai mengoreksi perilaku yang tidak tepat; (3) Perspektif hak individu (individual right perpective) yaitu berusaha melindungi hak hak dasar individu selama tindakan disipliner; (4)Perpektif utilitarian (utilitarian perpective) yaitu berfokus kepada penggunaan disiplin hanya pada saat konsekuensi tindakan disiplin melebihi dampak negatifnya.

$$
\text { Rivai (2004:444) juga }
$$

menyebutkan ada tiga konsep dalam pelaksanaan tindakan disipliner yaitu (I) aturan tungku panas yaitu pendekatan untuk melaksanakan tindakan disipliner; (2) tindakan disiplin progresif yaitu untuk memastikan bahwa terdapat hokum minimal yang tepat terhadap setiap pelanggaran; (3) tindakan disiplin positif yaitu dalam banyak situasi, hukuman tindakan memotivasi pegawai mengubah suatu perilaku.

\section{METODE PENELITIAN}

\section{A. Jenis dan Pendekatan Penelitian}

penelitian ini adalah jenis penelitian survey dengan pendekatan kuantitatif deskriptif yang bertujuan untuk mendeskripsikan secara secara sistematis, dan proporsional tentang fokus penelitian dengan tingkat keabsahan data dan informasi yang reallible.

\section{B. Teknik Pengumoulan Data} Kuesioner ditujukan kepada responden untuk mendapatkan data primer yang terkait dengan variabel penelitian, yaitu kepemimpinan dan disiplin kerja.

Wawancara langsung (interview) yaitu teknik yang digunakan untuk mendapatkan infromasi dari informan yang berkaitan dengan variabel penelitian dengan menggunakan pedoman wawancara.(Interview guide).

\section{Teknik Pengumoulan Data I.Product Moment \\ Untuk menguji hipotesis} hubungan dua variabel pada unit analisis yang sama yaitu aparatur birokrasi, pengaruh variebsl independen (XI dan X2) 
terhadap variabel dependent (Y) digunakan rumus "Korelasi Product moment" sebagai berikut:

(E xy)

$$
r=x y(E X 2)(E Y 2)
$$

untuk mengetahui tingkat koefisien korelasi yang dihasilkan, maka dapat diberikan interpretasi berdasarkan interval koefisien yang dirumuskan oleh Sugiono (2004: 77), yaitu: 0,00-0,199 (sangat rendah); $0,20-0,399$ (rendah); 0,40 - ,599 (sedang); 0,60 - 0,799 (kuat), dan 0,8- 100,00 (sangat kuat)

2. Regresi linier berganda

Regresi linier berganda Teknik analisis yang digunakan dalam penelitian ini yaitu: regresi liner berganda dengan pengukuran skala Litkert $(5,4,3,2$, dan I) dengan bantuan SPSS versi 23 for windows.

Untuk uji hipotesis digunakan uji $\mathrm{F}$ pada tarap kepercayaan 0,05.dan 0,01 model penelitian tersebut dapat dirumuskan persamaan sebagai berikut

$$
\begin{aligned}
& Y=a+B X I+X 2+e \\
& \text { Keterangan } ; \\
& Y=\text { Kinerja pegawai } \\
& a=\text { bilangan konstanta } \\
& B=\text { koefisien arah regresi } \\
& X I=\text { Kepemimpinan } \\
& X 2=\text { Disiplin kerja hipotesis } \\
& \text { e }=\text { kesalahan penganggu. } \\
& \quad \text { Pengujian }
\end{aligned}
$$
digunakan untuk mengukur kekuatan hubungan antar variabel dependen $(X I-X 3)$ dengan variabel independen $(Y)$ dengan menggunakan uji $t$ pada taraf kepercayaan 0,05.

\section{Pengujian}

hipotesis digunakan untuk mengukur kekuatan hubungan antar variabel dependen $(X I-X 3)$ dengan variabel independen $(Y)$ dengan menggunakan uji t pada taraf kepercayaan 0,05 .

3. Tebel Frekuensi dan Persentase

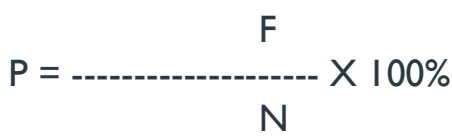

Keterangan:

$\mathrm{P}=$ Jumlah Populasi

$\mathrm{F}=$ Frekunsi jawaban

$\mathrm{N}=$ Distribusi

responden.

\section{HASIL \\ PEMBAHASAN}

konsep kinerja pada dasarnya dapat dilihat dari dua sisi, yaitu kinerja pegawai(perindividu) dan kinerja organisasi.

Kinerja adalah gambaran mengenai tingkat pencapaian pelaksanaan tugas dalam suatu organisasi, dalam upaya mewujudkan sasaran, tujuan, misi, dan visi organisasi tersebut (Bastian,200I:329). Pegawai adalah orang yang melakukan pekerjaan dengan mendapatkan imbalan jasa berupa gaji dan tunjangan dari pemerintah. Unsur manusia sebagai pegawai maka 
tujuan badan (wadah yang telah ditentukan) kemungkinan besar tecapai sebagaiman yang diharapkan. Pegawai inilah yang mengerjakan segala pekerjaan atau kegiatan penyelenggaraan pemerintahan. Berdasarkan penjelasan diatas, maka pengertian kinerja pegawai adalah hasil kerja seseorang dalam suatu organisasi

Gambaran mengenai tingkat pencapaian pelaksanaan tugas yang dilakukan oleh seluruh pegawai yang ada disuatu organisasi atau instansi pemerintah.

Meningkatkan kinerja dalam sebuah organisasi atau instansi pemerintah merupakan tujuan yang ingin dicapai oleh organisasi dan instansi pemerintah dalam memaksimalkan suatu kegiatan. Kinerja organisasi adalah totalitas hasil kerja yang dicapai suatu organisasi. Kinerja pegawai dan kinerja organisasi memiliki keterkaitan yang sangat erat, tercapainya tujuan organisasi.

Kinerja pegawai tidak dapat dilepaskan dari sumber daya yang dimiliki oleh organisasi, sumber daya yang digerakkan atau dijalankan pegawai yang berperan aktif sebagai pelaku dalam upaya mencapai tujuan organisasi tersebut.

Berdasarkan perspektif tersebut hasil yang dicapai oleh seorang paratur menurut ukuran profesionalisme dalam pekerjaannya diaplikasikan dalam prilaku, kecerdasan dana kemampuan sesuai dengan peranan, kegiatan dan tugas yang telah ditentukan. Aparatur Kantor Camat Buntu Batu BatuKabupaten Enrekang dalam memberdayakan dan memaksimalkan suatu kinerja dalam memberikan pelayanan Publik kepada masyarakat, diperlukan pemahaman dalam melaksanakan tugasnya, sehingga menghasilkan apa yang menjadi tujuan yang telah ditatapkan.

Organisasi pemerintahan dalam hal ini Kantor Camat Buntuk Kabupaten Enrekang menggunakan alat untuk mengukur suatu kinerja birokrasi publik, indikator yang digunakan menurut Baban Sobandi dan para ahli lainnya dalam bukunya yang berjudul Desentralisasi dan Tuntutan Penataan Kelembagaan daerah sebagai berikut: (I) Keluaran; (2) hasil; (3) Kaitan dengan usaha deengan pencapaian target (Sobandi, 2006 : 179).

Pertama, keluaran adalah sesuatu yang diharapkan lansung dicapai dari suatu kegiatan yang berupa fisiki atau non fisik. Suatu kegiatan yang berupa fisik maupun non fisik yang diharapkan oleh suatu organisasi atau instansi dapat dirasakan lansung oleh masyarakat. Ukuran keluaran disini dapat dilihat dari dua sub indikator yaitu kualitas sumber daya aparatur yang ada dikantor 
Camat Buntu Batu Kabupaten Enrekang, kuantitas merupakan suatu hasil pelayanan yang dapat memenuhi uji kualitas.

Kedua, hasil adalah mengukur pencapaian atau hasil yang terjadi karena pemberian layanan.

segala sesuatu yang

mencerminkan berfungsinya

keluaran kegiatan pada jangka menengah (efek lansung). Maka segala kegiatan yang dilakukan atau dilaksanakan pada jangka menengah oleh Kantor Camat Buntu Batu Kabupaten Enrekang harus dapat memberikan efek langsung kepada kegiatan tersebut.

Ketiga, kaitan usaha dengan pencapaian adalah usaha yang dilakukan oleh kantor Camat Buntu Batu Enrekang dalam memberikan pelayanan publik bagi masyarakat bisa tercapai sesuai dengan tujuan pelayanan public.

Ukuran kaitan usaha disini dapat dilihat dari dua sub indikator yaitu ukuran, yaitu: (I) efisiensi yang mengkaitkan usaha dengan keluaran pelayanan. Berdasarkan pengertian diatas, maka mengukur sumber daya yang digunakan atau Biaya per unit keluaran, dan memberi informasi tentang keluaran di tingkat tertentu dari penggunaan sumber daya, menunjukan efisiensi relatif suatu unit jika dibandingkan dengan hasil sebelumnya, tujuan yang ditetapkan secara internal, norma atau standar yang bisa diterima atau hasil bisa dicapai oleh organisasi yang setara. Biaya merupakan laporan biaya per unit hasil dan kaitan biaya dengan hasil sehingga manajemen publik dan masyarakat bisa mengukur pelayanan yang telah diberikan.

Kinerja aparatur dalam memberdayakan standar operasipnal prosedur (SOP) harus dapat ditentukan dengan pencapaian target selama periode waktu yang dicapai organisasi. Berhasil tidaknya tujuan dan citacita dalam organiasasi pemerintah tergantung bagaimana proses kinerja itu dilaksanakan. Kinerja tidak lepas dari faktor-faktor yang mempengaruhi.

Berikut faktor-faktor yang mempengaruhi kinerja sebagaimana yang telah dikemukakan oleh Keith Davis dalam buku Anwar Prabu Mangkunegara, yaitu: (I) Faktor kemampuan. Secara psikologis , kemampuan ability yang terdiri dari kemampuan potensi; (2) IQ dan kemampuan reality, Knowledge dan Skill. Artinya pimpinan dan karyawan yang memiliki IQ superior, gifted dan genius dengan Pendidikan yang memadahi untuk jabatan dan terampil dalam menjalankan pekerjaan sehari-hari maka akan mudah menjalankan kinerja maksimal; (2) Faktor motivasi. Motivasi diartiakan sebagai suatu 
sikap attitude pimpinan dan karyawan terhadap situasi kerja dilingkungan kerja organisasinya. Mereka yang bersikap positif terhadap situasi kerjanya akan menunjukkan motivasi kerja tinggi dan sebaliknya jika mereka berpikir negative terhadap situasi kerjanya akan menunjukkan motivasi kerja yang rendah. Situasi yang dimaksud meliputi hubungan kerja, fasilitas kerja, iklim kerja, kebijakan pimpinan, pola kepemimpinan kerja dan kondisi kerja (Mangkunegara, 2000:13).

Kinerja dipengaruhi oleh beberapa faktor pendukung dan penghambat berjalannya suatu pencapaian kinerja yang maksimal, faktor tersebut meliputi faktor yang berasal dari intern maupun ektern. Menilai suatu kinerja apakah sudah berjalan dengan yang direncanakan perlu diadakan suatu evaluasi kinerja sebagaimana yang dikemukakan oleh Andrew E. Sikula dalam buku Anwar Prabu Mangkunegara. “ Evaluasi kinerja atatu penilaian merupakan suatu evaluasi yang sistematis dari pekerjaan pegawai dan potensi yang dapat dikembangkan. Penilaian dalam proses penafsiran atau penentuan niali, kualitas atau status dari beberapa objek orang ataupun suatu barang". (Mangkunegara 2006: 69).

Aparatur sebagai pelayan masyarakat, harus memberikan pelayanan terbaik untuk mencapai suatu kinerja. Kenyataannya untuk mencapai kinerja yang diinginkan tidaklah mudah, banyak hambatan-hambatan yang harus dilewati. Menurut Keith Davis dalam A.A. Anwar Prabu Mangkunegara terdapat beberapa faktor yang mempengaruhi pencapain kinerja, faktor tersebut berasal dari factor kemampuan dan motivasi aparatur. Berdasarkan hal tersebut maka akan dijelaskan sebagai berikut: "Faktor yang mempengaruhi pencapaian kinerja adalah factor kemampuan (ability) dan faktor motivasi (motivation), yang dirumuskan sebagai berikut: "Human Performance $=$ Ability + Motivation, Motivation $=$ Atitude + Situation, Ability $=$ Knowledge + Skill" (Mangkunegara, 2005: I3)

Aparatur dalam pencapaian kinerja harus memiliki kemampuan dan motivasi kerja. Kemampuan yang dimiliki aparatur dapat berupa kecerdasan atau bakat. Motivasi yang dimiliki aparatur dilihat melalui sikap dan situasi kerja yang kondusif, karena hal ini akan berhubungan dengan pencapaian prestasi kerja atau kinerja aparatur pada lingkungan Kantor Camat Buntu Batu memberikan pelayanan kepada masyarakat.

\section{Selanjutnya}

Sastrohardiwiryo (2002: III) menjelaskan bahwa umumnya unsur-unsur kinerja adalah sebagai berikut : (I) Prestasi 
kerja, merupakan hasil kerja yang dicapai oleh seorang tenaga kerja dalam melakasankan tugas dan pekerjaan yang dibebankan kepadanya; (2) Tanggung jawab, adalah kesanggupan seorang tenaga kerja dalam menyelesaikan tugas dan pekerjaan yang di serahkan kepadanya sebaikbaiknya dan tepat waktu (3) Kejujuran, Merupakan ketulusan hati tenaga kerja dalam melaksakan tugas dan pekerjaan serta kemampuan untuk tidak menyalah gunakan wewenang yang telah dibebankan kepadanya; (4) Kerjasama, Merupakan kemauan tenaga kerja untuk bekerja sama dengan orang lain dalam menyelesaikan tugas dan perkerjaan yang diamanatkan, sehingga mencapai daya guna dan hasil guna yang sebesar-besarnya (5) Kepemimpinan, adalah kemampuan yang dimiliki seorang tenga kerja untuk meyakinkan orang lain (tenaga kerja lain) sehingga dapat dikerahkan secara maksimal untuk melaksanakan tugas pokok.

Sejalan dengan hak tersebut, maka peniliaan kerja, erat kaitannya dengan standar kenirja perlu diruumuskan untuk dijadikan bahan acuan dalam comparative standar (standar perbandingan). Standar perbandingan terhadap apa yang dicapai dengan apa yang diharapkan. Dengan kata lain standar tersebut dapat dijadikan patokan dalam menilai tanggung jawab terhadap apa yang dilakukan

Manajemen budaya kadangkala memfokuskan diri pada pengembangan nilai bersama dan mendapat komitmen untuk nilai bersama tersebut. Nilai ini berkaitan dengan jenis perilaku yang dipercaya manajemen sesuai kepentingan perusahaan. Nilai inti dari bisnis mengekspresikan keyakinan tentang apa yang dianggap penting oleh manajemen mengenai bagaimana fungsi perusahaan dan bagaimana orangorang seharusnya berperilaku. Tujuannya untuk memastikan bahwa keyakinan ini juga dimiliki dan dilaksanakan karyawan. Strategi manajemen budaya seharusnya menganalisis perilaku yang sesuai dan kemudian dibawa ke dalam proses, seperti manajemen kinerja, yang akan mendorong pengembangan perilaku tersebut.

\section{KESIMPULAN}

Berdasarkan hasil analisis pengaruh kepemimpinan dan disiplin kerja terhadap kinerja birokrasi pelayanan publik pada Kantor Camat Buntu Batu Kabupaten Enrekang, maka dapat kemukakan beberapa kesimpulan, sebagai berikut:

I. Hasil penelitian menunjukkan bahwa kepemimpinan Camat berpengaruh nyata terhadap kinerja birokrasi pelayanan publik Kecamatan Buntu Batu hal ini dibuktikan dengan Tabel frekuensi mendeskripsikan 
penilaian responden terhadap variabel bebas kepemimpinan (XI) sebesar 58,30\%; dan Product moment mendeskripsikan pengaruh: kepemimpinan (XI) sebesar $54,20 \%$ dengan koefisien korelasi ( $r$ hit $5.192>r$ tab 0,45 I signifikan pada taraf 0,05 $(T$ hit 6.37I $>T$ tab 4,26) $=$ HI ditrima; hal ini berarti bahwa penerapan gaya kepemimpinan Camat dengan gaya kepemimpinan

Demokratik akan meningkatkan kinerja pelayanan publik di kantor Camat Buntu Batu .

2. Hasil penelitian menunjukkan bahwa disiplin kerja berpengaruh nyata terhadap kinerja birokrasi pelayanan publik di kantor Camat Buntu Batu.hal ini dibuktikan dengan kedisipilinan kerja (X2) sebesar $67,88 \%$ dan motivasi (X2) sebesar $45,50 \%$ dengan koefisien korelasi ( $r$ hit 4,555 $>r$ tab 0,45I) signifikan pada taraf 0,05 ( $\mathrm{T}$ hit 3,555 > T tab 4,26) $=\mathrm{HI}$ diterima, yang artinya bahwa kinerja birokrasi pelalayan publik sangat ditentukan oleh penerapan dimensi kepatuhan dan ketaatan pegawai dalam melaksanakan aturan yang berlaku.

3. Hasil penelitian menunjukkan bahwa kepemimpinan dan disiplin kerja secara bersamasama berpengaruh nyata terhadap kinerja birokrasi pelayanan publik pada Kantor Camat Buntu Batu. Hal ini berarti bahwa jika penerapan gaya kepemimpinan dan disiplin kerja meningkat secara bersama-sama, maka kinerja birokrasi pelayanan public di Kantor Camat Buntu Batu akan optimal.

4. Faktor-faktor yang mempengaruhi variabel kepemimoinan dan disiplin kerja yaitu: (I) Budaya kerja sebesar 83,22\%; dan lingkungan kerja 90,97 yang berrti bahwa dalam rangka menerapkan

kepemimpinan gaya mengedepankan harus memperhatikan atau budaya kerja dan lingkungan kerja secara selektif, sehingga dapat mewujudkan kinerja birokrasi pelayanan publik yang bertanggung jawab sesuai dengan SOP.

\section{DAFTAR PUSTAKA}

[I] Agus Purwoko, 2014. Pengaruh Kepemimpinan dan Disiplin Kerja terhadap Kinerja Karyawan Pada Pt. Tri Mandiri Selaras Samarinda

[2] Arikunto Suharsimi, (2000), Manajemen Penelitian, Jakarta, Rineka Cipta. 
[3] Arep dan Tanjung. 2003. Manajemen Motivasi, Penerbit PT. Grasindo, Jakarta

[4] Ahmad S Ruky. 2002. Sistem Manajemen Kinerja. PT Gramedia Pustaka. Utama. Jakarta.

[5] Anwar

Prabu Mangkunegara. 2006.

Evaluasi Kinerja Sumber Daya Manusia. Jakarta: Refika Aditama.

[6] Aditya

Reza, Regina, 2010, Pengaruh

Gaya Kepemimpinan, Motivasi, dan. Disiplin Kerja terhadap Kinerja Karyawan PT. Sinar Santosa

[7] Andhika Ivona dan Murtiningtyas. 2012 . Kebijakan

Kepemilikan Kepemilikan Institusional, Profitabilitas, Risiko Bisnis terhadap Kebijakan Hutang. Accounting Analyis Journal, Vol. I, No. 2. ISSN 22526765.

[8] Anwar

Prabu Mangkunegara. 2005.

Sumber Daya Manusia perusahaan. Remaja. Rosdakarya: Bandung.

[9] Budi, Setiyawan dan Waridin. 2006. Pengaruh Disiplin Kerja Karyawan dan Budaya Organisasi Terhadap Kinerja di Divisi Radiologi RSUP Dokter Kariadi, Semarang:
JRBI. Vol 2. No 2. Hal: I8I198

[10] Bernardin, H. John. 2003. Human Resources Management: An Experiential. Approach, 3rd edition, McGraw-Hill//rwin, New York.

[II] Griffin, 2000, Manajemen Sumber Daya Manusia dan Ketenaga kerjaan. Jogyakarta : Graha Ilmu.

[12] Hasibuan, Malayu S.P, 2003, Manajemen Sumber Daya Manusia, Edisi Revisi,. Bumi Aksara, Jakarta.

[13] Hasibuan, 2003, Manajemen Sumber Daya Manusia (Edisi revisi), Jakarta: Grasindo.

[14] Henry Simamora. 2004. Manajemen Sumber Daya Manusia. Edisi Ke-3. STIE YKPN.

[15] Hasibuan, 2004. Manajemen Dasar,Pengertian, dan Masalah. Penerbit Bumi Aksara, Jakarta.

[16] Hasibuan, Malayu S.P. 2005. Manajemen Sumber Daya Manusia, Edisi Revisi. Bumi Aksara, Jakarta.

[17] Hasibuan, Malayu S.P, 2006, Manajemen Dasar, Pengertian, dan. Masalah,Edisi Revisi, Bumi Aksara:Jakarta.

[18] Hasibuan, Malayu S.P. 200I. Manajemen Sumber Daya Manusia. Jakarta : PT. Bumi Aksara. 
[19] Hadari, Nawawi dan Martini Hadawi. (1990). Administrasi Personel untuk

[20] Produktivitas Kerja. Jakarta: Haji Masagung.

[2I] Istianto, Bambang. 2009. Manajemen Pemerintahan Dalam Persepektif Pelayanan Publik. Jakarta : Mitra Wacana Media.

[22] Jamaluddin Ahmad, 2005, metode penelitian administrasi public,Gavana Media, Yogyakarta.

[23] Komarudin, 1992, Ensiklopedia Manajemen. Jakarta : Bumi Aksara.

[24] Kusriyanto, Bambang, 1993, Meningkatkan Produktivitas Karyawan, Jakarta: LPM.

[25] Mustafa Hasbar,20I4, Menguak prilaku Organisasi sector public antara teori dan aplikasi, penerbit ombak, Yogyakarta.

[26] Muchdarsyah Sinungan, (1995), Produktivitas apa dan Bagaimana. Jakarta: Bumi Askara.

[27] Masduki. 2004, Menjadi Broadcaster Profesional, Pustaka Populer, Yogyakarta

[28] Mathis, dan Jackson, 2002, Manajemen Sumber Daya Manusia, Edisi pertama. Bandung : CV Pustaka Setia.

[29] Moekijat. 2002.

Manajemen Sumber Daya
Manusia: Manajemen Kepegawaian. Mandar Maju. Jakarta.

[30] Nitisemito, 200I.

Manajemen Personalia, Jakarta : Graha Indonesia.

[3I] Rivai, Veithzal.2005. Kepemimpinan Dan Perilaku Organisasi, PT. Raja Grafindo Persada.

[32] Suharto, Edi. 2005. Membangun Masyarakat Memberdayakan Rakyat. Bandung: PT. Refika Aditama.

[33] Veithzal Rivai, 2004, "Manajemen Sumber Daya Manusia Untuk. Perusahaan,Cetakan Pertama, Jakarta, PT. Raja GrafindoPersada. 
